\title{
Filamentous Fungi Associated with the Spoilage of Post-Harvest Sweet Orange Fruits (Citrus Sinensis) Sold in Awka Major Markets, Nigeria
}

\author{
Onuorah Samuel $^{1, *}$, Obika Ifeanyi ${ }^{2}$, Okafor Ugochukwu $^{1}$ \\ ${ }^{1}$ Department of Applied Microbiology and Brewing, Nnamdi Azikiwe University Awka, Nigeria \\ ${ }^{2}$ Department of Zoology, Nnamdi Azikiwe University Awka, Nigeria
}

Copyright (C) 2015 by authors, all rights reserved. Authors agree that this article remains permanently open access under the terms of the Creative Commons Attribution License 4.0 International License

\begin{abstract}
Sweet oranges are prone to spoilage by filamentous fungi as a result of their high levels of sugars and low $\mathrm{P}^{\mathrm{H}}$ values. These fungi are known to produce toxins which are deleterious to human health. This study was therefore conducted to isolate, characterize and identify the filamentous fungi associated with the spoilage of sweet oranges sold in major Awka Markets, Nigeria. Thirty sweet orange fruits purchased from Eke-Awka, Temporary Site, Nodu, Ifite and Amaenyi Markets were used for the study. The average filamentous fungal count of the spoilt sweet orange fruits was $2.0 \times 10^{3} \mathrm{cfu} / \mathrm{ml}, 1.3 \times 10^{3} \mathrm{cfu} / \mathrm{ml}, 2.1 \times 10^{3}$ $\mathrm{cfu} / \mathrm{ml}, 1.6 \times 10^{3} \mathrm{cfu} / \mathrm{ml}$ and $1.8 \times 10^{3} \mathrm{cfu} / \mathrm{ml}$ for the samples from Eke-Awka, Temporary Site, Nodu, Ifite and Amaenyi Markets respectively. The fungi were identified as Aspergillus niger, Rhizopus stolonifer, Mucor mucedo, Penicillium digitatum, Fusarium oxysporum and Aspergillus flavus. The percentage distribution of the fungi was $27.5 \%$, $22.5 \%, 15.0 \%, 10.0 \%, 7.5$ and 17.5\% for Aspergillus niger, Rhizopus stolonifer, Mucor mucedo, Penicillium digitatum, Fusarium oxysporum and Aspergillus flavus respectively. Aspergillus niger caused the highest degree of spoilage. Good agricultural practices, adequate storage facilities and good handling practices must be put in place to reduce the incidence of these fungi in sweet oranges thereby minimizing their spoilage.
\end{abstract}

Keywords Filamentous Fungi, Spoilage, Sweet Orange Fruits, Major Awka Markets, Nigeria

\section{Introduction}

Sweet orange (Citrus sinensis) belongs to the family Rutaceae and is one of the major commercial fruit crops that is widely eaten fresh or taken as juice [1]. It is one of the most important winter fruit crops of the world and is mainly cultivated in the tropical and subtropical regions with a mediterranean climate in over 137 countries on six continents [2-4]. Sweet orange is an important fruit crop in international trade next to grapes.

In Nigeria, the Sweet orange-producing States are Benue, Taraba, Oyo, Imo, Ebonyi, Kwara, Kogi, Kaduna, Ogun, Ondo, Ekiti, Edo, Delta and Osun States [5]. Sweet orange is a major source of vitamins especially Vitamin C, Vitamin A and Vitamin B, calcium, potasium, magnesium, carotenoids, flavonoids, antioxidants, acids, essential oils, dietary fibres, folate, iron, manganese, zinc, sodium and lodine [6].

Sweet oranges have been reported to prevent cancer, asthma, obesity, arthritis, kidney stones, coronary heart diseases, high blood pressure and stroke and are also necessary for the maintenance of healthy mucus membranes, skin and vision [7-10].

One of the limiting factors that influence the fruits economic value is the relatively short shelf life caused by pathogens. In developing countries, where protection and proper handling of fresh sweet orange fruit is inadequate, losses during transit and storage can represent an excess of $50 \%$ of the harvested crops [11].

Spoilage of Sweet oranges refers to any changes in the condition of the fruits in which they become less palatable. These conditions may be accompanied by alterations in taste, smell, appearance or texture due to the activities of spoilage microorganisms [12]. The fruits contain high levels of sugars and their low $\mathrm{P}^{\mathrm{H}}$ values make them particularly desirable to fungal spoilage.

Sweet oranges are susceptible to a large number of fungal diseases that can cause severe economic losses. These diseases include Sweet orange scab, Citrus black spot disease and Powdery mildew [13-15].

Many moulds and yeast are involved in the spoilage of sweet oranges fruits. These include Aspergillus spp, Fusarium spp, Geotrichum spp, Penicillium spp, Rhizopus spp, Saccharomyces spp, Candida spp and Trichosporon spp. These fungi render the fresh fruits unfit for human consumption by causing their deterioration, leading to the 
reduction in quality and texture, off-flavour development and loss of nutrients hence the objective of this work was to isolate and identify the filamentous fungi associated with the spoilage of post-harvest sweet orange fruits sold in major Awka Markets, Nigeria in order to put in place control measures that would reduce the losses due to spoilage.

\section{Materials and Methods}

\subsection{Samples Collection and Processing}

Thirty sweet orange fruits were purchased from Eke-Awka, Temporary Site, Nodu, Ifite and Amaenyi Markets in Awka, Nigeria and kept for two weeks for spoilage to occur. Thirty healthy orange fruits were later purchased from the same Markets and used for the pathogenicity test (fifteen for the test and fifteen as controls) after the fungal isolation. All the samples were transported to the microbiology laboratory of Nnamdi Azikiwe University Awka in separate sterile polythene bags for the filamentous fungal isolation, characterization and identification.

\subsection{Filamentous Fungal Isolation}

The spoilt sweet orange fruits were surface-sterilized with cotton wool soaked in $70 \%$ alcohol and cut into small segments $(3 \mathrm{~mm}$ diameter) using sterile scalpels. The segments were separately homogenized and serially-diluted with sterile distilled water. One milliliter of each homogenized suspension was dispensed into a conical flask containing sterile potato dextrose agar (PDA) and 2.0 percent chloramphenicol.

The contents were properly mixed and dispensed aseptically into sterile petri dishes which were thereafter incubated at $28^{\circ} \mathrm{C}$ for seven days. The colonies that developed were subcultured onto sterile potato dextrose agar plates to obtain pure cultures and later stored on sterile PDA slants for characterization and identification.

\subsection{Characterization and Identification of the Filamentous Fungi}

The pure cultures of the filamentous fungi were identified on the basis of cultural and morphological features such as colony growth pattern, conidial morphology and pigmentation using the slide culture technique and microscopic examination.

\subsubsection{Slide Culture Technique}

A small portion of the aerial mycelia was picked using a sterile inoculating needle and inoculated on a slide containing prepared potato dextrose agar, which was incubated at room temperature for 24 hours after which it was viewed under the microscope. The identity of the filamentous fungi was confirmed with the aid of a mycological atlas.

\subsubsection{Microscopic Examination}

Microscopic examination was also carried out using the lactophenol cotton blue stain. A drop of the stain was placed on a clean grease-free slide. A small portion of the filamentous fungal culture was emulsified in the stain after which the slide was covered with a coverslip avoiding bubbles. The slide was thereafter viewed under the microscope.

\subsection{Pathogenicity Tests of the Filamentous Fungi}

Each of the filamentous fungi was tested on healthy orange fruits for its ability to induce spoilage using the methods described by Baiyewu et al [16] and Chukwuka et al [17]. Thirty healthy oranges were used (fifteen as test samples and fifteen as control samples). The test samples were washed with tap water and rinsed with distilled water after which they were surface-sterilized with $70 \%$ ethanol. A sterile scalpel was used to make holes in each of the fruits after which the fungi were inoculated separately into the fruits and the core of the fruits replaced. The point of inoculation of the fruits was sealed with petroleum jelly to prevent contamination. The inoculated fruits were then placed in sterile polythene bags (one fruit per bag) and each moistened with wet balls of absorbent cotton wool to create a humid environment and incubated at $28^{\circ} \mathrm{C}$ for five days and observed for symptom development. The filamentous fungi were re-isolated from the inoculated fruits and compared with the original isolates. The decay rate of the fruits was also determined after two weeks of the inoculation of the fungi into the healthy oranges by measuring the rot diameter of each spoilt fruit.

\section{Results}

The average filamentous fungal counts of the spoilt sweet orange fruits are shown in Table 1 . The counts were 2.0.x $10^{3}$ $\mathrm{cfu} / \mathrm{ml}, 1.3 \times 10^{3} \mathrm{cfu} / \mathrm{ml}, 2.1 \times 10^{3} \mathrm{cfu} / \mathrm{ml}, 1.6 \times 10^{3} \mathrm{cfu} / \mathrm{ml}$ and $1.8 \times 10^{3} \mathrm{cfu} / \mathrm{ml}$ for the fruits from Eke-Awka, Temporary Site, Nodu, Ifite and Amaenyi Markets respectively.

Table 1. Average filamentous fungal counts of the spoilt Sweet orange fruits

\begin{tabular}{cc}
\hline Market & Average Filamentous Fungal Count $(\mathrm{cfu} / \mathrm{ml})$ \\
\hline Eke-Awka & $2.0 \times 10^{3}$ \\
Temporary site & $1.3 \times 10^{3}$ \\
Nodu & $2.1 \times 10^{3}$ \\
Ifite & $1.6 \times 10^{3}$ \\
Amaenyi & $1.8 \times 10^{3}$ \\
\hline
\end{tabular}

The colonial and microscopic characteristic of the filamentous fungi from the spoilt sweet orange fruits are presented in Table 2. The fungi were identified as Aspergillus niger, Rhizopus stolonifer, Penicillum digitatum, Mucor mucedo, Fusarium oxysporum and Aspergillus flavus. 
Table 2. Colonial and Microscopic Characteristics of the Filamentous fungi from the spoilt Sweet Orange Fruits

\begin{tabular}{|c|c|c|c|}
\hline Isolate & Colonial features & Microscopic features & Identify \\
\hline 1 & Colonies were black in colour & $\begin{array}{l}\text { Conidiophores were unbranched with } \\
\text { rounded ends that bore conidia }\end{array}$ & Aspergillus niger \\
\hline 2 & $\begin{array}{l}\text { Colonies were white in colour and } \\
\text { cottony }\end{array}$ & $\begin{array}{c}\text { Sporangia containing spores were seen. } \\
\text { Rhizoids were also present }\end{array}$ & Rhizopus stolonifer \\
\hline 3 & Colonies were green in colour & $\begin{array}{l}\text { Brush-like Conidiophores bearing } \\
\text { Conidia were present }\end{array}$ & Penicillum digitatum \\
\hline 4 & $\begin{array}{c}\text { Colonies were cottony and black in } \\
\text { colour }\end{array}$ & $\begin{array}{c}\text { Sporangia bearing spores were seen. } \\
\text { Rhizoids were absent }\end{array}$ & Mucor mucedo \\
\hline 5 & Colonies were pink in colour & Conidia were spindle shaped & Fusarium oxysporum \\
\hline 6 & $\begin{array}{l}\text { Colonies were white in colour at first } \\
\text { and later black. The reverse side was } \\
\text { pale yellow }\end{array}$ & $\begin{array}{l}\text { Hyphae were septate, simple and thick- } \\
\text { walled. Conidiophores bearing conidial } \\
\text { heads containing conidia were seen }\end{array}$ & Aspergillus flavus \\
\hline
\end{tabular}

The occurrence of the filamentous fungi in the Sweet orange fruits is shown in Table 3. Aspergillus niger were isolated from the fruits from all the markets, Rhizopus stolonifer from the fruits from Eke-Awka, Nodu, Ifite and Amaenyi markets while Mucor mucedo were isolated from the fruits from all but Nodu market. In addition, Penicillium digitatum were isolated from Nodu, Ifite and Amaenyi markets, Fusarium oxysporum from the fruits from Temporary site and Ifite markets while Aspergillus flavus were isolated from the fruits from Eke-Awka, Nodu and Amaenyi markets.

Table 3. Occurrence of the filamentous fungi in the spoilt Sweet orange fruits

\begin{tabular}{ccccccc}
\hline Market & $\begin{array}{c}\text { Aspergillus } \\
\text { niger }\end{array}$ & $\begin{array}{c}\text { Rhizopus } \\
\text { stolonifer }\end{array}$ & $\begin{array}{c}\text { Mucor } \\
\text { mucedo }\end{array}$ & $\begin{array}{c}\text { Penicillium } \\
\text { digitatum }\end{array}$ & $\begin{array}{c}\text { Fusarium } \\
\text { oxysporum }\end{array}$ & $\begin{array}{c}\text { Aspergillus } \\
\text { flavus }\end{array}$ \\
\hline Eke-Awka & + & + & + & - & - & + \\
Temporary Site & + & - & + & - & + & + \\
Nodu & + & + & - & + & + & - \\
Ifite & + & + & + & + & - & + \\
Amaenyi & + & + & + & + & & \\
\hline$+=$ detected & & & & & &
\end{tabular}

The distribution of the filamentous fungi in relation to the markets is presented in Table 4. The percentage distribution of $25.5 \%, 10.0 \%, 37.5 \%, 12.5 \%$ and $15.0 \%$ were obtained for the samples from Eke-Awka, Temporary site, Nodu, Ifite and Amaenyi markets respectively.

Table 4. Distribution of the filamentous fungi in relation to the Markets

\begin{tabular}{|c|c|c|c|c|c|c|c|}
\hline Markets & $\begin{array}{l}\text { Aspergillus } \\
\text { niger } \\
\text { (n) }\end{array}$ & $\begin{array}{l}\text { Rhizopus } \\
\text { stolonifer } \\
\text { (n) }\end{array}$ & $\begin{array}{c}\text { Mucor } \\
\text { mucedo } \\
(\mathrm{n})\end{array}$ & $\begin{array}{l}\text { Penicillium } \\
\text { digitatum } \\
\text { (n) }\end{array}$ & $\begin{array}{l}\text { Fusarium } \\
\text { oxysporum } \\
\text { (n) }\end{array}$ & $\begin{array}{l}\text { Aspergillus } \\
\text { flavus } \\
\text { (n) }\end{array}$ & $\begin{array}{c}\% \\
\text { Distribution }\end{array}$ \\
\hline Eke-Awka & 2 & 3 & 3 & 0 & 0 & 2 & 25.0 \\
\hline $\begin{array}{c}\text { Temporary } \\
\text { Site }\end{array}$ & 1 & 0 & 1 & 0 & 2 & 0 & 10.0 \\
\hline Nodu & 5 & 4 & 0 & 2 & 0 & 4 & 37.5 \\
\hline Ifite & 1 & 1 & 1 & 1 & 1 & 0 & 12.5 \\
\hline Amaenyi & 2 & 1 & 1 & 1 & 0 & 1 & 15.0 \\
\hline
\end{tabular}

$\mathrm{n}=$ number of isolates 
The percentage distribution of the filamentous fungi in the spoilt Sweet orange fruits is presented in Table 5. The percentage distribution were $27.5 \%, 22.5 \%, 15.0 \%, 10.0 \%$, $7.5 \%$ and $17.5 \%$ for Aspergillus niger, Rhizopus stolonifer, Mucor mucedo, Penicillium digitatum, Fusarium oxysporum and Aspergillus flavus respectively

Table 5. Percentage Distribution of the filamentous fungi isolated from the spoilt sweet orange fruits

\begin{tabular}{ccc}
\hline Filamentous fungi & No. of isolates & Distribution (\%) \\
\hline Aspergillus niger & 11 & 27.5 \\
Rhizopus stolonifer & 9 & 22.5 \\
Mucor mucedo & 6 & 15.0 \\
Penicillium digitatum & 4 & 10.0 \\
Fusarium oxysporum & 3 & 7.5 \\
Aspergillus flavus & 7 & 17.5 \\
\hline
\end{tabular}

The decay rate of the filamentous fungi in the healthy Sweet orange fruits is presented in Table 6 . The rot diameter of Aspergillus niger was $35 \mathrm{~mm}$, that of Rhizopus stolonifer $30 \mathrm{~mm}$ while Mucor mucedo, Penicillum digitatum, Fusarium oxysporum and Aspergillus flavus had $25 \mathrm{~mm}$, $20 \mathrm{~mm}, 10 \mathrm{~mm}$ and $28 \mathrm{~mm}$ respectively.

Table 6. Decay rate of the filamentous fungi in the Sweet Orange fruits

\begin{tabular}{cc}
\hline Filamentous fungi & Rot Diameter $(\mathrm{mm})$ \\
\hline Aspergillus niger & 35 \\
Rhizopus stolonifer & 30 \\
Mucor mucedo & 25 \\
Penicillium digitatum & 20 \\
Fusarium oxysporum & 10 \\
Aspergillus flavus & 28 \\
\hline
\end{tabular}

\section{Discussion}

The filamentous fungi associated with the spoilage of Sweet orange sold in Awka major Markets, Nigeria were studied. The average counts ranged between $1.3 \times 10^{3} \mathrm{cfu} / \mathrm{ml}$ and $2.1 \times 10^{3} \mathrm{cfu} / \mathrm{ml}$. The sample from Nodu Market had the highest count of $2.1 \times 10^{3} \mathrm{cfu} / \mathrm{ml}$ while those from Temporary Site market had the least count of $1.3 \times 10^{3} \mathrm{cfu} / \mathrm{ml}$ (Table 1). The filamentous fungi isolated from the spoilt orange fruits were identified as Aspergillus niger, Rhizopus stolonifer, Penicillium digitatum, Mucor mucedo, Fusarium oxysporum and Aspergillus flavus (Table 2). Ojo et al [18] also isolated Aspergillus niger, Fusarium oxysporum, Penicillium digitatum and Rhizopus stolonifer from the rotted orange fruits displayed for sale in five different market places in five major cities in Oyo State in South Western Nigeria. Akintobi et al [19] also isolated Aspergillus niger, Penicillium digitatum and Rhizopus stolonifer from deteriorating citrus fruits in Ibadan, Southwestern Nigeria.

Mohammed et al [20] also isolated Fusarium oxysporum, Aspergillius niger, Rhizopus stolonifer and Penicillium digitatum from decayed sweet orange fruits collected from Lapai, Niger State, Nigeria. Tafinta et al [21] also isolated Aspergillus niger, and Rhizopus stolonifer from sweet orange fruits in Sokoto State.

Aspergillus niger were isolated from the samples from all the markets while Rhizopus stolonifer were isolated from the samples from all except the Temporary Site Market. Mucor mucedo were isolated from the samples from all except Nodu market, Penicillium digitatum were isolated from Nodu, Ifite and Amaenyi markets, Fusarium oxysporum were isolated from the samples from Temporary site and Ifite markets while Aspergillus flavus were isolated from the samples from Eke-Awka, Nodu and Amaenyi markets (Table 3).

The distribution of the filamentous fungi in relation to the markets showed that $25.0 \%, 10.0 \%, 37.5 \%, 12.5 \%$ and $15.0 \%$ of the fungi were isolated from the samples from Eke-Awka, Temporary Site, Nodu, Ifite and Amaenyi markets (Table 4).

Aspergillus niger had the highest percentage distribution of $27.5 \%$, Rhizopus stolonifer $(22.5 \%)$, Mucor mucedo $(15.0 \%)$, Penicillium digitatum $(10.0 \%)$, Fusarium oxysporum (7.5\%) and Aspergillus flavus (17.5\%) (Table 4).

Tafinta et al [21] however reported the percentage distribution of $17 \%$ and $36 \%$ for Aspergillus niger and Rhizopus stolonifer in the sweet orange samples they studied in Sokoto. Akintobi et al [19] reported a frequency of occurrence of $50 \%, 10 \%$ and $50 \%$ for Aspergillus niger, Penicillum digitatum and Rhizopus stolonifer respectively in their orange samples from Ibadan South western Nigeria.

The decay rate of the filamentous fungi in the sweet orange fruits showed that Aspergillus niger produced the highest rot with a diameter of $35 \mathrm{~mm}$, Rhizopus stolonifer $(30 \mathrm{~mm})$, Mucor mucedo $(25 \mathrm{~mm})$, Penicillum digitatum (20mm), Aspergillus flavus $(28 \mathrm{~mm})$ while Fusarium oxysporum produced the lowest rot with a diameter of $10 \mathrm{~mm}$. Tafinta et al [21] however reported that Rhizopus stolonifer was the most active fungi that caused the rot of the orange fruits they studied, with a rot diameter of $45 \mathrm{~mm}$ while Aspergillus niger was the least active with a rot diameter of $25 \mathrm{~mm}$. Bali et al [22] reported that the black mold, Aspergilus niger caused the post harvest spoilage of sweet orange and acid lime in the field.

This result agreed with the reports of Baiyewu et al [16] and Chukwuka et al [17]. The occurrence of these fungi in the sweet orange fruits was as a result of contamination during harvesting, transportation, storage and handling.

These fungi isolated from the sweet orange fruits have been reported to produce toxins [23]. These moulds have also been reported to produce secondary metabolites such as aflatoxins which have been associated with cancer of the liver, aflatoxicosis and acute hepatitis in humans especially in the developing world [16]. These fungi have also been reported to be pathogenic and could cause diseases [24]. Aspergillus spp are known to produce several toxic metabolites such as malformins, naphthopyrones and ochratoxins which pose a serious health hazard to human and 
animal health $[25,26]$.

In Nigeria, sweet oranges are usually transported to areas of high demand in open vehicles with no preservation facilities. In the markets, they are usually displayed in open trays, baskets, pans, and tables thereby exposing them to contamination by microorganisms including the filamentous fungi. It is therefore pertinent that adequate storage facilities must be put in place for these important fruits. Good hygiene must also be observed during their handling and processing. In addition, orange fruits with any symptom of spoilage must be properly disposed off and not be sold and consumed by the public because of their adverse effects on health.

\section{Conclusions}

This work showed that the filamentous fungi isolated from the sweet orange fruits examined were associated with their spoilage as shown by the varying degree of symptoms they produced when inoculated into the healthy fruits. These fungi are known to be toxigenic or pathogenic to health, therefore their presence in sweet oranges must be controlled. This should be achieved through proper washing of the harvested fruits, disinfection of transit containers, proper handling of the fruits to avoid injuries, adequate hygienic practices by the handlers, provision of good storage facilities and the use of safe food grade fungicides.

\section{REFERENCES}

[1] S. Gorinstein, O. Martin-Belloso, Y. Park, R. Haruenkit, A. Lojek, M. Ciz, A. Capsi, I. Libma, S. Traktenberg. Comparison of some biochemical characteristics of different citrus fruits. Food chemistry, Vol.74, No.3, 309-315, 2001. doi: 10. 1016/S0308-8146 (01) 00157-1.

[2] M. Ismail, J. Zhang. Post-harvest citrus diseases and their control. Outlook on Pest Management, Vol. 15, No.1, 29-35, 2004. Doi: $10.1564 / 15$ feb 12 .

[3] A.L. Piccinelli, M.G. Mesa, D.M. Armenteros, M.A. Alfonso, A.C. Arevalo, L. Campone, L. Rastrelli. HPLC-PDA-MS and NMR characterization of C-Glycosyl flavones in a hydro-alcoholic extract of citrus aurantifolia leaves with antiplatelet activity. Journal of Agricultural food Chemistry, Vol. 56, No.5, 1574-1581, 2008. Do1:10.1021/jf073485k.

[4] J. Terol, M. Cores, F. Tadeo, F. Andres, G. Soler, J. Brumos, D.J. Iglesias, S. Gotz, F. Legaz, E. Argout, C. Dossat, P. Ollitrault, P. Wincker, M. Talon, R. Moritton, B. Courtoic, E. Alos, J. Augusti, J.M. Colmenero, A. Conesa. Analysis of 13000 unique citrus clusters associated with fruits quality, production and salinity tolerance. Biomedical Central Genomics, Vol. 8, 31, 2007. doi:10.1186/1471-2164-8-31.

[5] M. Oyegun. Citrus Cultivation and processing. Raw Materials Update, Vol.3, No.1, 32-33, 2002. http: //www. Unilorin.edu.ng/publications/arekemase/publication I. pdf.

[6] D. Di Majo, M. Giammanco, M.L. Guardia, E. Tripoli, S.
Giammanco, E. Finotti. Flavones in citrus fruit: structure antioxidant activity relationship. Food Research International, Vol.38, No. 10, 1161-1166, 2005. Doi:10.1016/j.foodres.2005.05.001.

[7] E, Tripoli, M.L. Guardia, S. Giammanco, D. Di. Majo, M. Giammanco. Flavonoids: Molecular structure, biological activity and nutritional properties: A review. Food chemistry, Vol. 104, No.2, 466-479,2007. doi: 1016/j.foodchem.2006.11.054.

[8] S. Ejaz, A. Ejaz, K. Matsuda, W.L. Chae. Limonoids as cancer chemopreventive agents. Journal of the Science of Food and Agriculture, Vol.86, No.3, 339-345, 2006. Doi: $10.1002 /$ jsfa. 2396 .

[9] P.L. Crowell. Prevention and therapy of cancer by dietary monoterpenes. The journal of Nutrition, Vol. 129, No.3, 775S-778S, 1999. http://www.aromaticscience.com/preventi on-and.therapy-of-cancer.

[10] J.A. Manthey, N. Guthrie, K. Grohmann. Biological properties of citrus flavonoids pertaining to cancer and inflammation. Current Medicinal Chemistry, Vol.8, No.2, 135-153,2001. Doi: 10.2174/0929867013373723.

[11] J.W. Eckert, J.M. Ogawa. The chemical control of Post harvest diseases: Subtropical and Tropical fruits. Annual Review of Phytopathology, Vol.23, 421-454, 1985. Doi: 10.1146/annurev.py.23.090185.002225

[12] O.O. Akinmusire. Fungal species associated with the spoilage of some edible fruits in Maiduguri, North Eastern, Nigeria. Advances in Environmental Biology, Vol.5, No. 1, 157-161, 2011. http://www.aensiweb. com/old/aeb/2011/157-161.

[13] M. Kunta, P.B.D. Sa, M.E. Palm, J. Rascoe, K.W. Timmer, J.V. Da Graca, R.L. Mangan, N.S.A. Malik, B. Salas, A. Satpute, M. Setamou, M. Skaria. Sweet orange scab with a new scab disease syndrome of citrus in the U.S.A. associated with Elsinoe australis. Tropical plant pathology, Vol. 38, No.3, 203-212, 2013. http://www.dx.doi.org/10.1590/S198256762013005000003 .

[14] M.B. Sposito, L. Amorim, R.B. Bassanezi, P.T. Yamamoto, M.R. Felippe, A.B.C. Czermainski. Relative importance of inoculum sources of Guignarda citricarpa on the citrus black spot epidemic in Brazil. Crop protection, Vol. 30, No. 12, 1546-1552, 2011. doi: 10. 1016/j.cropro.2011.08.007.

[15] J.W. Hyun, L.W. Timmer, S.C. Lee, S.H Yun, S.W. Ko, K.S. Kim. Pathological characterization and molecular analysis of Elsinoe isolates causing scab diseases of citrus in Jeju Island in Korea. Plant Disease, Vol. 85, No.9, 1013-1017, 2001. http://www.dx.doi.org/10.1094/PDIS.2001.85.9.1013.

[16] R.A. Baiyewu, N.A. Amusa, O.A. Ayoola, O.O. Babalola. Survey of the postharvest diseases and aflatoxin contamination of marketed pawpaw fruit (Carica Papaya L.) in South Western Nigeria. African Journal of Agricultural Research, Vol. 2, No.4, 178-181, 2007. http://www.academi cjournals.org/AJAR

[17] K.S. Chukwuka, I.O. Okonko, A.A. Adekunle. Microbial Ecology of organisms causing pawpaw (Carica Papaya L.) fruit decay in Oyo State, Nigeria. American-Eurasian Journal of Toxicological Sciences, Vol.2, No. 1, 43-50, 2010. http://www.idosi.org/aejts/aejts 2 (1)10.htm.

[18] O.A. Ojo, O.A. Olaniran, K.A. Odelade. Survey of 
Postharvest Diseases and Aflatoxin contamination of marketed orange fruit (citrus sp) in major cities in Oyo State, Nigeria. International Journal of Applied plant pathology, Vol. 10, No. 6, 110-117,2013. http//www.currentsciencepubl isher.org/journal/ab/survey-of-the-post.

[19] A.O. Akintobi, I.O. Okonko, S.O. Agunbiade, O.R. Akano, O. Onianwa. Isolation and identification of fungi associated with the spoilage of some selected fruits in Ibadan, South Western, Nigeria. Academia Arena, Vol. 3, No.11, 1-10, 2011. http//www.science pub.net.

[20] D.S.S. Mohammed, K.D. Niranjan, D. Damisa, E. Bala, I.L. Muhammad, G.R. Muhammad, A. Yunusa. Fungi Associated with decayed sweet oranges (Citrus sinensis) collected from Lapai, Niger State, Nigeria. Indian Journal of Life Science, Vol. 2, No.2, 123-131, 2013. http//www.ijls.in/upload/1228639664chapter_26.pdf.

[21] I.Y. Tafinta, K. Shehu, H. Abdulganiyyu, A.M. Rabe, A. Usman. Isolation and identification of fungi associated with the spoilage of sweet orange (Citrus sinensis) fruits in Sokoto State. Nigerian Journal of Basic and Applied Sciences, Vol. 21, No.3, 193-196, 2013. http://www/ajol.info/index.php/njbas/article/downlaod/1101 $32 / 99862$
[22] R.V. Bali, B.M. Gopireddy, R.V. Chenga, R.K. Gurava, R.M. Chandrasekhar. Post harvest fungal spoilage in sweet orange (Citrus sinensis) and acid lime (Citrus aurentifolia swingla) at different stages of marketing. Agricultural Science Digest, Vol. 28, No.4, 265-267, 2008. http://www.researchgate.net/publication/259753640.

[23] R.R. AL-Hindi, A.R. AL-Najada, S.A. Mohammed. Isolation and identification of some fruit spoilage fungi: Screening of plant cell wall degrading enzymes. African Journal of Microbiology Research, Vol. 5, No. 4, 443-448, 2011. Doi: 10.5897/AJMR10.896.

[24] E.M. Monso. Occupational asthma in greenhouse workers. Current Opinion in Pulmonary Medicine, Vol. 10, No.2, 147-150, 2004.

http://www.ncbi.n/m.nih.gov/pubmed/15021185.

[25] M. Peraica, B. Radic, A. Lucic, M. Pavlovic. Toxic effects of mycotoxins in humans. World Health Organization, Vol.77, No.9, 754-766, 1999. http://www.who.int/bulletin/ar chives/77(9) 754 .

[26] E. Petzinger, A. Weidenbach. Mycotoxins in the food chain: The role of ochratoxins. Livestock production science, Vol. 76, 245-250, 2002.

http://www.researchgate.net/publication/22309324 